\title{
光干渉縞を用いたナノサイズ微粒子径の非接触・インライン計測
}

\section{The non-contact and in-line measurement of nano size particles with laser interference fringes}

\author{
○ 学 粎 宏人(筑波大院) 正 金子 暁子(筑波大) 正 阿部 豊(筑波大) 池 昌俊(Apptex LLC)
}

Hiroto SAKAKI, University of Tsukuba, 1-1-1 Tennodai, Tsukuba, Ibaraki, 305-8573

Akiko Kaneko, University of Tsukuba

Yutaka Abe, University of Tsukuba

Masatoshi Ike, Apptex LLC, 2-16G Nagakunidai, Tsuchiura, Ibaraki, 300-0810

\begin{abstract}
Fine particle size measurement technique with laser interference fringes is proposed as one of the in-line measurement technique to the diameter of several hundred nano meter particles. The objective of this study is to examine the principle of this measurement technique with laser interference fringes. First, we visualize the flow structure in the flow cell with Particle Image Velocimetry (PIV). Flow structure in the flow cell is appeared stable. Second, we visualize the laser interference fringe images with high-speed video camera. And we identify the fringe images moving through the test cell. Finally, we measure the time variation of the intensity of the laser interference fringes by using two photodiodes. It is confirmed that the voltage signal depends on fine particle size. Also, the voltage signal depends on flow rate.
\end{abstract}

Key Words: Particle size measurement, Fine particles, Laser interference fringes

\section{1. 緒言}

近年, 電子デバイス分野において，製品の微細化・低コス 卜化，製造過程の短時間化が進んでいる.製品の微細化に伴 い, 洗浄に用いられる超純水や薬液に含まれる微粒子は歩留 まりを悪化させる要因になる．また，製造ラインは止めずに 微粒子を検出することが製造過程の短時間化に重要となる. これらを満たすために，粒径 $100 \mathrm{~nm}$ 以下の可能な限り微小 な粒子を非接触かつインラインで計測することが求められ ている.

ニーズを満たす技術として，現在，散乱光方式が主流と なっている. 散乱光方式は, 微粒子が混入した試料流体に レーザー光を照射し，その散乱光の強さから粒径を決定して いる. しかしながら，散乱光方式では，微小な粒子の測定に 限界があることが知られている。 そこで，新たな計測法とし て, 光干渉縞を用いた手法が提案されている(1).この手法は, 微粒子が混入した試料流体にレーザー光を照射し，その回折 現象による干渉縞のパターンを解析して, 粒径を決定してい る.しかしながら，この手法の基礎的原理および微小な粒子 を計測するための適用性が不明である.

本研究では, 新たに提案された光干渉縞を用いた微粒子径 計測法の計測原理を検討することを目的とする. 本報告では， フローセル内流動の可視化計測, 流動する粒子により生じる 干渉縞の可視化計測およびフォトダイオードを用いた干渉 縞の電気信号計測を行い, 光干渉縞を用いた微粒子径計測法 の計測原理の検討を行った結果について報告する.

\section{2. 実験装置}

Fig. 1 に実験装置の概略図を示す. 本実験装置は大きく分 けて, レーザー光学系, フローセル, 受光部および循環ポン プから成る. 計測する粒子以外の粉塵の混入を防ぐために, ポンプには運転時の発塵量が少ないバイモルポンプを採用 し, フローセルの下流に設置した. また, 流体が流れるチュー ブおよびフローセルとチューブを接続するための継手の材 質は粉塵の出にくいPFA(フッ素樹脂系)を採用した.

Fig. 2 に本実験で使用したフローセルの概略図を示す。フ ローセルの材質は石英ガラスである. 計測領域が円管の場合, 屈折率の影響により正確な計測が困難となるため, 計測領域 のみ矩形管としている. 矩形管部の寸法は, 内部が一辺 $3 \mathrm{~mm}$ の正方形断面で，管の長さは $50 \mathrm{~mm}$ である。両端の円管部

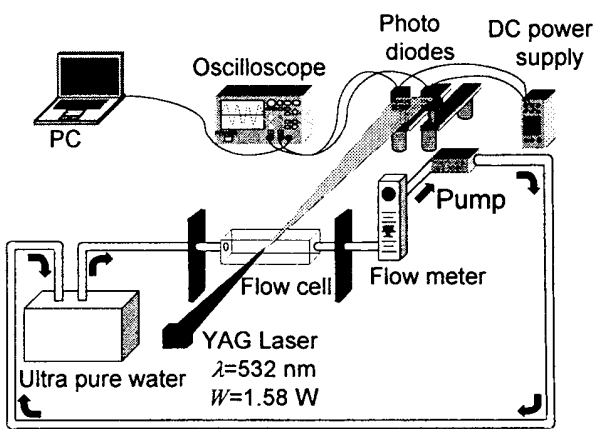

Fig. 1 Schematic diagram of the experimental apparatus.

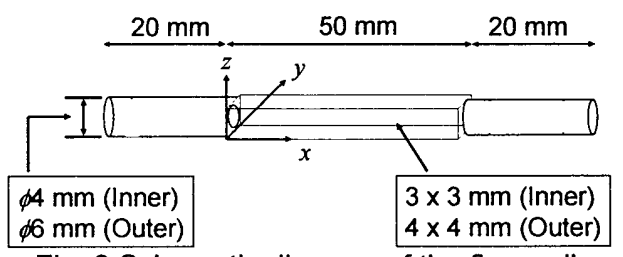

Fig. 2 Schematic diagram of the flow cell.

の内径は $4 \mathrm{~mm}$ である. また，座標軸を Fig. 2 に示すように とり，原点を矩形管部の入りロ下部にとる.

\section{3. 実験方法および実験条件}

3-1 フローセル内流動可視化観測実験 フローセル内流動 を可視化観測するために, トレーサー粒子として粒径 $4 \mu \mathrm{m}$, 比重 1.02 のナイロン粒子を超純水中に混入する.これをフ ローセル内に供給し, 面積式流量計により流量を調節する. フローセル内の流れが定常になった後に, 波長 $\lambda=532 \mathrm{~nm}$, 出 力 $W=1.58 \mathrm{~W}$ の YAG レーザーにより, 水平方向から厚さ 1.8 $\mathrm{mm}$ のシート状レーザーをフローセルに照射する．レーザー により照射された2次元断面をハイスピードビデオカメラを 用いてフローセルの鈆直上方向からの流動を撮影する.

3-2 移動干渉縞可視化観測実験 フローセル中央に集光さ せたレーザー光を通過する粒子により生じる干渉縞をフ ローセルから $1 \mathrm{~m}$ 離れたスクリーン上に投影し, ハイスピー ドビデオカメラを用いて撮影する.

3-3 干渉縞の電気信号計測実験 干渉縞の電気信号計測に は，フォトダイオード2つを用いた．2つのフォトダイオー 
ドを光軸から左右に $20 \mathrm{~mm}$ ずつ離し，光軸からのにらみ角 が約 $26^{\circ}$ の位置に設置した. 流れ方向に対し上流側のフォト ダイオードおよび下流側のフォトダイオードにより検出さ れる粒子からの散乱光信号の変化を $2 つ$ つオトダイオード を同期させて計測した．ただし，2つの信号の判別を容易に するために下流側のフォトダイオードの信号は正負を反転 させて取得した. 散乱光の入らない条件をはじめに計測し, ノイズの状況を確認した上で，得られる信号を計測した。

\section{4. 実験結果および考察}

4-1 フローセル内流動可視化計測 Fig. 3 に流量 $10 \mathrm{~mL} / \mathrm{min}$ におけるフローセル内の平均流速分布を示す. 横軸には $x$ 方 向流速 $u$ を, 縦軸には $y$ 方向位置 (流れ方向に垂直な方向)を 示す. Fig. 3 より，円管から矩形管へ流入した直後の $x=0.36$ $\mathrm{mm}$ における流速は遅いものの, フローセル中央付近 $(x=25$ $\mathrm{mm}$ かつ $y=1.5 \mathrm{~mm}$ ) では, 定常的な流れとなることがわかる. また, 流量 $10 \mathrm{~mL} / \mathrm{min}$ から断面平均流速を算出すると, 約 23.6 $\mathrm{mm} / \mathrm{s}$ であることから, Fig. 3 の結果は妥当だと考えられる. 4-2 移動干渉縞可視化計測 Fig. 3 の流動に対し, フローセ ル内に集光させたレーザー光を通過する粒子により生じる 干涉縞の挙動を撮影したときの画像の一例を Fig. 4 に示す. Fig. 4 の左図を基準時間 $t=0 \mathrm{~s}$ としたときの $1.5 \mathrm{~s}$ 後の画像を 右図に示す. Fig. 4 より, 発生する干涉縞はフローセルの流 動同様一定方向に流れていることがわかる. また, $1.5 \mathrm{~s}$ 間に フォトダイオードの計測位置に換算して $40 \mathrm{~mm}$ 移動してい ることから, 干渉縞の移動速度は流速と同程度の值を示すこ とがわかる。

4-3 干渉縞の電気信号計測 フォトダイオード2つを用いて 干渉縞の電気信号を計測した結果の一例を Fig. 5 に示す. 横 軸にはフォトダイオードにより信号を取得し始めてからの 時間を, 縦軸にはフォトダイオードにより取得した電気信号 をとっている. Fig. 5 の上流側のフォトダイオードの信号に 対して, 周波数解析を行った結果を Fig. 6 に示す. Fig. 6 か ら，卓越した周波数は $39.1 \mathrm{~Hz}$ と $58.6 \mathrm{~Hz}$ であることがわか る. $58.6 \mathrm{~Hz}$ は電源による周波数だと考えられるので, $39.1 \mathrm{~Hz}$ が粒子を検出した際の周波数だと考えられる。したがって， Fig. 5 のように得られる信号一つ一つに対して, Fig. 6 のよう な周波数解析を行うことで電源以外の卓越周波数を求めた. この周波数から周期を算出し，これを目安として粒径を検出 したときの波形を決定した.この決定した波形に対し, Fig. 5 に示す上流側のフォトダイオードと下流側のフォトダイ オードの信号ピークの時間差 $\Delta t$ およびフォトダイオード間 のピーク電圧值の差 $\Delta V$ を定義した.

Fig. 7 に横軸に $\Delta t$ を，縦軸に $\Delta V$ をとり，流量の影響を調べ た結果を示す.いずれの流量においても， $\Delta t$ の増加に伴い $\Delta V$ が減少する傾向を示した．これは，レーザー光をフローセル 中央に集光させたことにより, エネルギー密度が高いスポッ 卜径の位置では粒子が通過する時間が短く, 一方, ここから 離れるに従いエネルギー密度が小さくなり, 粒子の通過する 時間は長くなるためだと考えられる. また, 流量の増加に伴 い $\Delta t$ が減少することがわかる.これは流量が増加したことで, フローセル内の流速が増加したためだと考えられる。

\section{5. 結言}

流量が $10 \mathrm{~mL} / \mathrm{min}$ のとき，フローセル中央付近では，定 常的な流れとなることが確認された。

- 干渉縞の挙動を可視化観測した結果, 干渉縞の移動速度 は流速と同程度の值を有することを確認した。

・ 干渉縞が発生する条件の下，フォトダイオード2つを用 いて光の信号強度を計測した結果，フォトダイオード間 の信号ピークの時間差とピーク電圧値に相関があり，流 量によって相関に違いがあることを確認した。

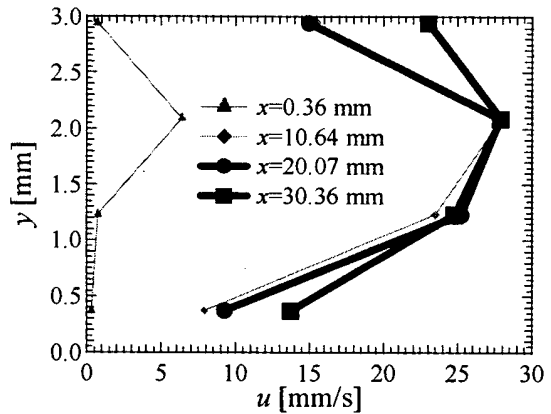

Fig. 3 Average flow velocity distribution in the flow cell
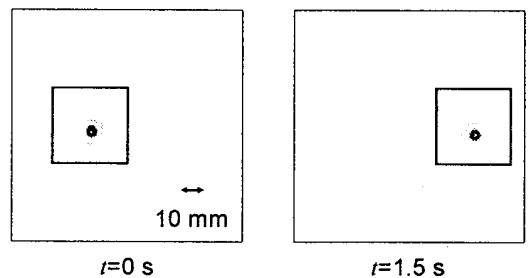

$t=1.5 \mathrm{~s}$

Fig. 4 Snapshot of moving fringe image

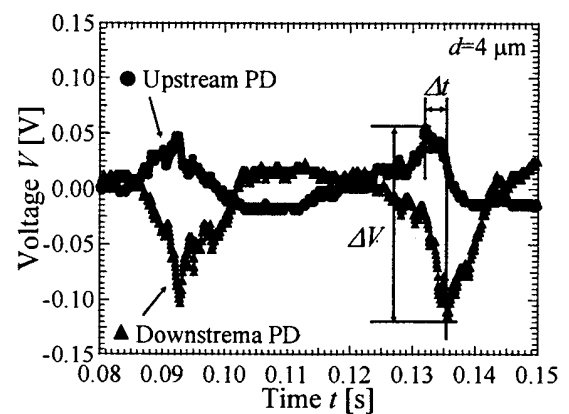

Fig. 5 Raw signals detected with the photodiodes

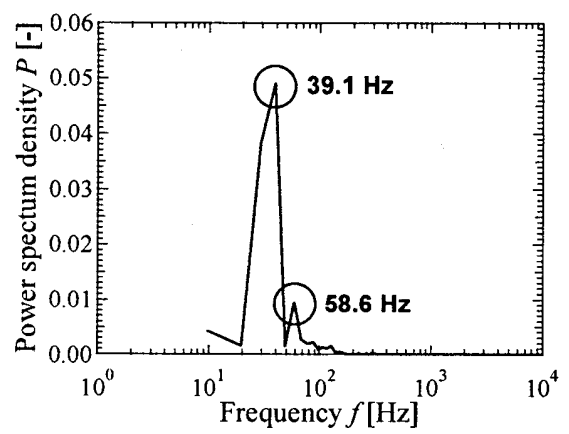

Fig. 6 FFT of voltage

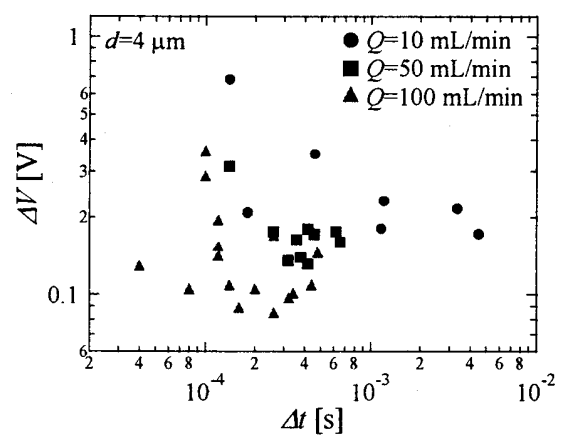

Fig. 7 Correlation between $\Delta t$ and $\Delta V$

参考文献

(1) 北斗電子(株), 液体中の粒子のサイズの検出方法および 装置, 特許 (特開 2009-8602) 